\title{
A NEW FAUNA FROM THE COLORADO GROUP OF SOUTHERN MONTANA.
}

\author{
By John B. Reeside, Jr.
}

\section{INTRODUCTION}

This paper describes a small but interesting fauna collected in 1921 by W. T. Thom, jr., Gail F. Moulton, T. W. Stanton, and K. C. Heald in the Crow Indian Reservation in southern Montana. The locality is in sec. 36, T. 6 S., R. 32 E., Big Horn County, and is 2 miles east of the Soap Creek oil field.

The stratigraphic section in the Soap Creek oil field was described briefly by Thom and Moulton in a press notice issued by the United States Geological Survey December 5, 1921, entitled "The Soap Creek oil field, Crow Indian Reservation, Mont." It was described also in a later and more general paper. ${ }^{1}$ The youngest beds present near the oil field belong to the Niobrara formation, but in the adjacent parts of the Crow Reservation to the east and north higher formations are present and are in part included in the section given below. The part of the section from the Cloverly formation to the Niobrara formation, inclusive, is derived from the publications mentioned above and from data kindly supplied by Mr. Thom. The thicknesses given for the Eagle sandstone and the Telegraph Creek formation apply especially to the vicinity of Pryor Creek, some 30 miles north of the Soap Creek oil fierd. The included lists of fossils are based on the writer's determinations.

Partial section of formations exposed in the Crow Indian Reservation, Mont.

Sandstones and some shales; at base the massive Virgelle sandstone member. This formation contains Scaphites hippocrepis (Dekay), Scaphites n. sp. aff. S. aquisgranensis Schlueter, Inoceramus aff. I. lobatus Goldfuss, Placenticeras syrtale (Morton), Placenticeras meeki Boehm, Placenticeras planum Hyatt, Baculites ovatus Say, Baculites asper Morton, Baculites n. sp. aff. B. anceps Lamarck, and many other fossils.

1 Thom, W. T., jr., Oil and gas prospects in and near the Crow Indian Reservation, Mont.: U. S. Geol. Survey Bull. 736, pp. 35-53, 1922 (Bull. $730-\mathrm{B})$
Feet.

Telegraph Creek formation................. 320-350

Sandstones and shales. This group of beds contains at places in the upper part a fauna like that of the Eagle sandstone, but in the lower beds it contains Uintacrinus sp., Marsupites sp. (identified by Frank Springer), Inoceramus deformis Meek var., Ostrea cf. O. congesta Conrad, Baculites sp., Puzosia (Latidorsella) n. sp., and Scaphites n. sp. aff. S. geinitzi D'Orbigny.

Niobrara formation (top formation of Colorado

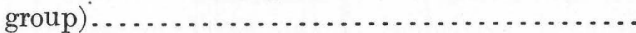

Bluish calcareous shale in upper and lower parts; dark shale in middle. In the upper part it contains Uintacrinus socialis Grinnell (identified by Frank Springer), Yoldia sp., Inoceramus, large thick-shelled species, Ostrea congesta Conrad, Lunatia concinna (Hall and Meek), Tessarolax cf. T. hitzi White, Baculites sp., Scaphites vermiformis Meek and Hayden, and fish scales. In the middle part it contains Inoceramus aff. I. lamarcki Parkinson, Inoceramus umbonatus Meek and Hayden, Inoceramus, large thick-shelled species, Pteria aff. P. nebrascensis (Evans and Shumard), Anatina aff. A. subgracilis (Whitfield), Veniella goniophora Meek, Cardium n. sp., Fusus sp., Volutoderma sp., Baculites aff. B. anceps Lamarck, Baculites asper Morton, Scaphites vermiformis Meek and Hayden. In the lower part it contains Inoceramus, large thick-shelled species, Ostrea congesta Conrad, and the basal bed, a zone of large yellow concretions, contains Yoldia sp., Nemodon sp., Barbatia n. sp., Inoceramus fragitis (Hall and Meek)?, Inoceramus (Actinoceramus) n. sp., Veniella goniophora Meek, Callista tenuis (Hall and Meek), Corbula cf. C. nematophora Meek, Dentalium sp., Gyrodes aff. G. petrosa (Morton), Turritella aff. T. whitei Stanton, Anchura sp., Nautilus sp., Baculites sp., and Scaphites vermiformis Meek and Hayden.

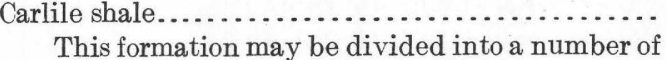
units as follows:.

Dark shale with whitish septarian nodules containing Inoceramus labiatus (Schlotheim), $V e$ niella goniophora Meek, Corbula aff. C. nematophora Meek, Pseudomelania? sp., Fusus sp., Prionocyclus wyomingensis Meek. Thickness 50 feet.

Zone of large yellowish sandstone concretions. Thickness 5 feet.

Dark shale. Thickness 35 feet.

Shale with thin hard rusty red concretions and layers containing Inoceramus fragilis Hall and 
Meek, Inoceramus cf. I. lamarcki Parkinson, Veniella sp., Volutoderma? sp., Baculites gracilis Shumard, Scaphites warreni Meek and Hayden, Prionotropis aff. P. woolgari (Mantell). Thickness 30 feet.

Dark shale. Thickness 60 feet.

Bluish calcareous shale containing in its lower part the fauna described in this paper. Thickness 100 feet.

Dark shale and bentonite. Thickness 145 feet. Frontier formation.........................

Chiefly dark shale with bentonite but with a zone of thin coarse sandstones near the top. Shark teeth the only fossils observed.

Mowry shale.

Hard bluish-white shale with layers of hard dark shale. Contains abundant fish remains but few other fossils.

Thermopolis shale..................... 550-800

Dark marine shale with streaks and lenses of light-colored sandstone containing Inoceramus labiatus (Schlotheim), Pteria aff. P. nebrascensis (Meek and Hayden), Ostrea sp., Entolium sp., Modiola n. sp., Gyrodes aff. G. depressa Meek, fish and turtle remains. Middle part of formation of dark clay and bentonite; lower part of dark marine shale.

Cloverly formation...................... 320-425

An upper member of sandy shale and thin-bedded rusty sandstone that may represent the Dakota sandstone of Upper Cretaceous age.

A middle member consisting of variegated shale where exposed along the Big Horn Mountains and containing Unio sp. and Viviparus? sp. and a basal member of thick coarse-grained conglomeratic sandstone. These divisions may represent the Fuson shale and Lakota sandstone, of Lower Cretaceous age.

\section{THE FAUNA AND ITS RELATIONS.}

The collection described in this paper contains five species of ammonites referred to three genera, two species of Inoceramus, an ostreid, and a gastropod.

The species are as follows:

Vascoceras thomi Reeside, n. sp.

Vascoceras moultoni Reeside, n. sp.

Vascoceras stantoni Reeside, $\mathrm{n}$. sp.

Vascoceras sp. undeterminable.

Pseudotissotia (Choffaticeras) sp.?

Helicoceras pariense White?

Inoceramus labiatus (Schlotheim).

Inoceramus sp. undetermined.

Ostrea or Exogyra sp.

Gastropod, undetermined.

This fauna is known from only this one locality in the Western Interior province of North America, and consequently its correlation must rest in large part on its position with relation to other faunal zones in the same stratigraphic section and in the adjacent
Feet. | region. It is therefore of interest to consider some of the faunal zones recognizable in the Cretaceous deposits of this province.

A series of more or less widespread and more or less distinctly defined faunal zones have long been recognized in the Cretaceous deposits of the Western Interior. The lowest zone to be considered here is well characterized only in the southern part of the province, where it contains Exogyra columbella Meek and Gryphaea newberryi Stanton as its guide fossils. This zone includes the Graneros shale of the central Great Plains, the basal part of the Mancos shale of New Mexico, Colorado, and Utah, and the Thermopolis shale of the north. At many places, especially in the north, it is nearly barren of fossils, and those present are not sufficiently restricted to serve as guide fossils.

Above this zone occurs a zone with an abundance of Inoceramus labiatus (Schlotheim). In the central Great Plains region this zone is contained in the Greenhorn limestone, and very few other fossils than the guide fossil have been found in it. In western Colorado and the adjacent region it is well marked in the lower part of the Mancos shale. It occurs in southern and central Wyoming in the Frontier formation and in northern Montana in the lower part of the Colorado shale.

Above this zone of Inoceramus labiatus lies a zone which contains as its more prominent and restricted species Scaphites warreni Meek and Hayden, several species each of Prionotropis, and Prionocyclus, Inoceramus fragilis $\mathrm{Hall}$ and Meek, Inoceramus dimidius White, and Ostrea lugubris Conrad. It very rarely contains Inoceramus labiatus (Schlotheim). This zone is perhaps the most sharply defined and most widely recognized of the series. It comprises the entire Carlile shale of the central Great Plains and Black Hills regions, part of the Mancos shale of western Colorado and adjacent regions, the Carlile shale of Wyoming, and part of the Colorado formation of Montana.

Above the zone of Scaphites warreni comes a zone which contains Uintacrinus socialis Grinnell, Inoceramus umbonatus Meek and Hayden, Inoceramus deformis Meek, and, especially in the north, Scaphites ventricosus Meek and Hayden and Scaphites vermiformis Meek and Hayden. A very abundant and locally restricted form of this zone is Ostrea congesta 
Conrad. Inoceramus labiatus is reported in the literature as occurring here also, but it has not been found in numerous recent collections, and its earlier assignment to the fauna of this zone is very probably due to the erroneous reference of local exposures of the Greenhorn limestone to the Niobrara formation in Nebraska, Kansas, and elsewhere prior to Darton's work in that region. In this zone falls the Niobrara formation of the Great Plains region, part of the Mancos shale of western Colorado and the adjacent regions, the Niobrara formation of Wyoming, and the upper part of the Colorado shale of northern Montana.

Above this zone of Uintacrinus and Scaphites vermiformis comes a zone containing Scaphites hippocrepis (DeKay), Scaphites n. sp. aff. S. aquisgranensis Schlueter, Placenticeras syrtale (Morton) and its allies, Placenticeras planum Hyatt, and Inoceramus aff. I. lobatus Goldfuss. In New Mexico this zone has yielded also Mortoniceras aff. M. delawarense (Morton). In Montana and in southwestern Colorado and adjacent parts of New Mexico there is a subzone at the base of this zone which lacks Scaphites hippocrepis and Scaphites aff. S. aquisgranensis but which contains Scaphites n. sp. aff. S. geinitzi D'Orbigny as its most distinctive form. The zone of Scaphites hippocrepis is represented by the Eagle sandstone and Telegraph Creek formation of southern Montana, part of the Cody shale of northern Wyoming, part of the Steele shale of central and southern Wyoming, and the upper part of the Mancos shale of southwestern Colorado and adjacent New Mexico. Presumably the basal part of the Pierre shale of the central - Great Plains and Black Hills regions represents this zone, though the distinctive species have not been found in it except in northeastern New Mexico. Above the zone of Scaphites hippocrepis other faunal zones may be recognized but will not be described in this paper.

The stratigraphic section at the Soap Creek oil field and in the adjacent country, as shown in the section given on page 25 , has afforded enough paleontologic data to determine the relative position of the fossils described in this paper. The beds containing the fauna include the highest bed in which Inoceramus labiatus occurs abundantly and lie immediately beneath beds with the characteristic fauna of the zone of Scaphites warreni. They are therefore to be correlated with at least the upper part of the Greenhorn limestone of the central Great Plains, though the occurrence of Inoceramus labiatus in beds some 800 feet lower in the section raises a doubt whether the beds containing Vascoceras represent all of the Greenhorn limestone as developed at such localities as those in eastern Colorado, where the Greenhorn limestone contains the only beds in which Inoceramus labiatus occurs, is only about 50 feet thick, and is separated from the Dakota sandstone by scarcely 200 feet of Graneros shale. It is possible that the relatively great thickness of Graneros shale present in the Black Hills region beneath the Greenhorn limestone is due entirely to greater deposition of material to form the shale without an appreciably greater lapse of time and that the Greenhorn limestone, which does not change much in thickness over the whole region, represents approximately the same time interval everywhere. If so, the beds containing Vascoceras may represent all the time interval of the Greenhorn limestone and its equivalents in various parts of the Western Interior. In central Montana the Mosby sandstone member of the Warm Spring shale ${ }^{2}$ occupies a position in the section similar to that of the beds containing Vascoceras. Inasmuch as the faunas of the two units have in common only Inoceramus labiatus they do not help in determining the relations between them. Perhaps the only suggestion offered is the occurrence of Metoicoceras whitei Hyatt in the Mosby sandstone. This species is most abundant in and most characteristic of the lower part of the Colorado group in southern Utah and in New Mexico and may indicate that the conditions which permitted the northward extension of Vascoceras as far as southern Montana were the same as those which permitted Metoicoceras to reach central Montana and that the Mosby sandstone and the beds containing Vascoceras represent the same time.

The only other occurrence of Vascoceras in North America is that at Cerro del Macho, in the State of Coahuila, Mexico, described by Böse. ${ }^{3}$ Here the associated fossils are more numerous, though none of the species seem to be identical with those from Montana, except Inoceramus labiatus. Böse has given a good summary

2 U. S. Geol. Survey Bull. 736, p. 172, 1922 (Bull. 736-F).

3 Böse, Emil, On a new ammonite fauna of the lower Turonian of Mexico: Texas Univ. Bull. 1856, pp. 173-257, 1918. 
of the distribution of the Vascoceras fauna and of its composition in all its principal occurrences. The fauna in its fullest and most typical development contains species of the ammonite genera Fagesia, Vascoceras, Mammites, Pseudaspidoceras, Neolobites, Pseudotissotia, Hoplitoides, and Thomasites. It is the Salmurian fauna of the European geologists and is widely distributed in the Mediterranean region. It occurs in the lower and middle Turonian of Portugal; the lower Turonian of Algeria, Tunis, and Egypt; the Turonian of the southern Sahara region; and in Brazil, Colombia, Peru, and Mexico. Faunas more or less related though not yet reported to contain Vascoceras occur in the Turonian of southern France, in India, and in Japan.

A comparison of the faunal succession in the Western Interior province with that in western Europe suggests the following correlations:

Western Interior.
Zone of Scaphites hippocrepis........ $\begin{aligned} & \text { Europe. } \\ & \text { Lower Campanian. } \\ & \text { Upper Santonian. }\end{aligned}$
$\begin{aligned} & \text { Zone of Uintacrinus, Inoceramus } \\ & \text { umbonatus, and Scaphites vermi- } \\ & \text { formis. }\end{aligned}$
$\begin{aligned} & \text { Zowe of Scaphites warreni............. Upper Turonian. } \\ & \text { Coniacian. }\end{aligned}$
$\begin{aligned} & \text { Zone of Inoceramus labiatus (Vasco- } \\ & \text { ceras at top in Montana)........... Lower Turonian. }\end{aligned}$

Apparently the present occurrence of Vascoceras would agree with the accepted assignment of the other known occurrences to the lower Turonian. It might be middle Turonian, if such a unit were recognized, but scarcely younger.

\section{DESCRIPTIONS OF SPECIES.}

\section{Genus VASCOCERAS Choffat.}

Choffat's original description ${ }^{4}$ is in part as follows:

Genus formed by shells more or less thick, sometimes globular, with ventral region rounded, ornamented in youth by ribs giving rise to tubercles on the flanks and to tubercles or elongated swellings on each side of the siphon. With some rare exceptions (Vascoceras subconciliatum), these lines of tubercles disappear in the adult stage, those of the umbilical border persisting longer, and the ventral region, or even all the visible part of the shell, is without ornamentation.

The length of the living chamber is from one-half to three-fourths of a whorl.

The suture shows two broad, rounded, weakly incised saddles, the third saddle much less important than it

4 Choffat, Paul, Les ammonées du Bellasien, des couches à Neolobites vibrayeanus, du Turonien, et du Sénonien: Faune crétacique du Portugal, vol. 1 , ser. 2 , p. $53,1898$. would be if the decrease were regular. The lobes are broad and divided by small saddles, in general not incised. From the position of these saddles the first lobe may be considered as divided into two or three parts. The second lobe is either simple or divided into two. [Translated.]

Choffat proposed four sections of the genus(a) monotuberculate forms with wide umbilicus, (b) subglobular forms with rounded umbilical border, (c) globular forms with angular or subangular umbilical border, $(d)$ multituberculate forms.

Pervinquière $^{5}$ later discussed Vascoceras, modifying somewhat Choffat's original description. Pervinquière's description is as follows:

Shell more or less thick, sometimes globular, with ventral region rounded, ornamented, in youth, by ribs bearing umbilical tubercles and marginal tubercles; these tubercles become less distinct in the adult stage (the umbilical tubercles remain distinct longer) and even disappear completely except on one group. There is never a median ventral tubercle. Living chamber measuring three-fourths of a whorl or even more. * * * Suture including two broad, rounded, little incised saddles; the third much smaller. Lobes broad and divided by small unincised saddles. [Translated.]

Pervinquière recognizes only three sections of the genus:

1. Group of $V$. gamai and of $V$. douvillei-durandi. Monotuberculate forms with wide umbilicus in the first species and more restricted in the second. There is every intermediate form between the two, as regards both general form and the greater or lesser rounding of the umbilical shoulder.

2. Group of $V$. harttiformis. Globular forms, with the umbilicus generally narrow, the umbilical shoulder more or less angular.

3. Group of V. subconciliatum. Multituberculate forms, departing notably from the preceding and approaching Mammites and the extreme forms of Acanthoceras.

Pervinquière points out that Vascoceras differs from the nearly related genus Fagesia Pervinquière in general form, in the much earlier disappearance of the ribs and tubercles, and especially in the suture. The suture of Fagesia has four slender lateral saddles, rounded in the upper part and trifid in subdivision; three lateral lobes, of which the first is profoundly bifid, the second less so, and the third pointed. Pervinquière adds, however, that some forms of Vascoceras are difficult to distinguish from Fagesia.

${ }^{5}$ Pervinquière, Léon, Études de paléontologie tunisienne, pt. 1 , Céphalopodes des terrains secondaires, pp. 331-332, 1907. 
The specimens in hand from Montana are a bit confusing in their relations. The general form, except perhaps for the width of the umbilicus, would permit an assignment to Fagesia, and the proportions and degree of incision of the suture fit those of Fagesia better than those of Vascoceras. Moreover, the umbilical tubercles are prominent, and there are traces of the ventral ribs in even the largest specimens. The younger whorls, however, show distinctly the umbilical and ventral tubercles of Vascoceras, the umbilicus is wider than shown in most of the figured specimens of Fagesia, and the suture in every specimen examined shows a pointed first and second lateral lobe, not bifid. The writer therefore assigns the specimens to Vascoceras rather than to Fagesia and further would place the first two of the species here described under Pervinquière's section 1 and the third under section 2.

\section{Vascoceras thomi Reeside n. sp.}

Plate XI, figures 1-2; Plate XII, figures 1-2; Plate XIII, figures 1-2; Plate XIV, figures 1-2; Plate XV, figures 1-7; Plate XVI, figures 1-6.

Shell stout, coronate. Earlier whorls not well shown in the type specimen except for the umbilical part, but apparently stout. Whorls above 115-millimeter diameter have a moderately depressed, oval cross section. Living chamber in type occupies three-fourths of a whorl and is apparently incomplete. Maximum diameter of type 165 millimeters. Umbilicus deep but fairly wide-about one-half the diameter of the shell in width. Umbilical shoulders rounded but well defined.

Sculpture of earlier whorls of type specimen seen only in the umbilicus, where it consists of large blunt conical nodes, seven to the whorl. On the last whorl of the type faint coarse ribs connect the umbilical nodes and a faint flattening on the venter seems to correspond to the space between the marginal nodes of the younger stages.

The suture shows a fairly broad ventral lobe and four lateral lobes and saddles, only moderately incised. The first lateral lobe is bluntly pointed, and the first lateral saddle is trifid.

A very large specimen (see Pl. XIII, figs. 1-2; Pl. XIV, figs. 1-2) assigned to this species has a maximum diameter of 260 millimeters and is apparently almost complete. The inner whorls are poorly preserved. The living cham$33372^{\circ}-25-3$ ber occupies three-fourths of a whorl; the aperture is not preserved. The suture of this specimen has wider saddles than those of the suture of the type but is otherwise like it. The umbilical nodes and obscure ventral ribs persist to the end of the specimen.

A small specimen assigned to this species (see Pl. XV, figs. 1-7) shows the sculpture and form of the stages following that at the diameter of 25 millimeters. The whorls to a diameter of about 40 millimeters are as high as wide and have strong rounded ribs that begin at the umbilical nodes, pass with a slight forward curve to the margin of the venter, where they form an elongated, poorly defined node, and then continue unbroken across the venter. Two or three ribs start from each umbilical node, and there are some intercalated ribs. On the half whorl from the diameter of 25 millimeters to the diameter of 40 millimeters there are four umbilical nodes and 15 ventral ribs. Above the diameter of 40 millimeters the ribs are less and less distinct on the venter, and at the diameter of 75 millimeters there are only indistinct folds. The umbilical nodes, however, remain large and blunt. The suture is much like that of the type.

A fourth specimen (see Pl. XVI, figs. 1-6), about the size of that just described, is assigned with some doubt to this species. The sculpture is much weaker than on the specimen just described and less than one would expect to find on the type at the same size. The cross section of the whorl is somewhat more depressed, and the suture is more incised. The specimen is closer to $V$. thomi than to the other species described in this paper and is therefore attached to it.

Vascoceras thomi may be recognized by its well-rounded venter and relatively high whorls. It differs from $V$. moultoni Reeside in possessing more elevated whorls and in sutural details; from $V$. stantoni Reeside in its much more elevated whorls and less angular umbilical shoulder It suggests somewhat $V$. silvanense Choffat ${ }^{6}$ but is apparently a much larger species and has a wider umbilicus and a different suture. It also suggests $V$. adonense Choffat ${ }^{7}$

${ }^{6}$ Choffat, Paul, Les ammonées du Bellasien, des couches à Neolobite vibrayeanus du Turonien, et du Sénonien: Faune crétacique du Portugal, vol. 1 , ser. 2, p. 57, pl. 8, fig. 5; pl. 21, fig. 9, 1898.

7 Idem, p. 59 , pl. fig. 9 , 3; pl. 21, fig. 12. 
but differs in the retention of the tubercles, in the form of the umbilicus, and in suture.

Vascoceras moultoni Reeside, n. sp.

Plate XVII, figures 1-2; Plate XVIII, figures 1-2.

Shell stout, coronate. Earliest stage seen in the single specimen available is at diameter of 80 millimeters. Whorl has broad, depressedoval cross section. Width of umbilicus more than half the diameter of the shell. Umbilical shoulder bluntly rounded. Living chamber and aperture unknown.

Sculpture of the visible whorls consists chiefly of large blunt conical nodes on the umbilical shoulders; umbilical wall smooth; venter smooth except for ill-defined broad, low ribs connecting the nodes.

Suture little incised; the lobes long and slender, the saddles rather broad and open; first lateral lobe pointed; first lateral saddle trifid.

Vascoceras moultoni may be recognized by the depressed-oval form of the cross section of the whorl and the relatively simple suture. It has a broader, more depressed whorl and simpler suture than $V$. thomi Reeside and a rounded rather than a subangular umbilical shoulder as in $V$. stantoni Reeside. It resembles some of the forms assigned in the literature to $V$. douvillei Choffat but is distinct from all of them in the persistence of the umbilical tubercles and in the suture.

Vascoceras stantoni Reeside, n. sp.

Plate XIX, figures 1-2; Plate XX, figures 1-3; Plate XXI, figures 1-3.

Shell stout, coronate. Earliest stage seen, at diameter of 35 millimeters, has whorl with depressed-ovate cross section. The form of the cross section changes little to the stage at diameter of 100 millimeters but thereafter becomes a broad pentagon. Width of umbilicus about half the diameter of the shell; umbilical shoulders subangular. Type entirely septate.

Sculpture of the whorl at diameter of 35 millimeters consists of coarse rounded ribs starting in pairs from a high conical umbilical node, passing to the margin of the venter, where they form blunt elongated nodes, and then continuing unbroken across the venter. There are four umbilical nodes and perhaps 10 ventral ribs on the half whorl succeeding the diameter of 35 millimeters. At the diameter of 70 millimeters, a whorl later, the whorl is smooth except for the umbilical nodes, and it remains so in all the later stages seen.

The suture shows four lateral lobes and saddles, moderately incised. The first lateral lobe is pointed, and the first lateral saddle trifid.

Two other specimens assigned to this species show a much later stage of growth than the type. The better preserved though less complete specimen (see Pl. XXI, figs. 1-3) would have measured about 275 millimeters in diameter. It has the same form of the whorl as the type and preserves even at so late a stage the umbilical tubercles and traces of the ventral ribs. The suture of this specimen was not seen.

Vascoceras stantoni may be recognized by its broad whorls with depressed pentagonal cross section and subangular umbilical shoulders. In the early stages it is not greatly different from $V$. thomi Reeside except that the ribs are finer, but in the later stages it departs sharply from that species in the form of the whorl. It differs from $V$. moultoni Reeside in its subangular umbilical shoulders and in sutural details. It is perhaps closest to $V$. harttiformis Choffat $^{8}$ in its general form but differs in the persistence of the umbilical nodes, in the greater width of the umbilicus, and in the suture.

Vascoceras sp.

Plate XX, figure 4.

The young stages of these American species of Vascoceras seem to be missing in most of the specimens in hand. One rather poorly preserved mold shows the exterior of younger whorls than any of the other specimens and is therefore figured.

\section{Genus PSEUDOTISSOTIA Peron.}

Subgenus CHOFFATICERAS Hyatî.

Pseudotissotia (Choffaticeras) sp.?

Plate XII, figures 3-6.

A single small specimen of an ammonite with sharp venter was obtained in cleaning the

8 Choffat, Paul, op. cit., p. 53, pl. 12, fig. 3; pl. 13, figs. 3-6; pl. 21, figs. 22-24, 1898. 
umbilicus of one of the large specimens of Vascoceras. This small specimen is nearly complete, preserving three-fourths of the last whorl unseptate, although only 13 millimeters in greatest diameter. The shell is very much compressed, discoid. The flanks of the whorls curve evenly from the umbilicus to the ventral keel. The umbilicus is moderately wide, about one-fourth the diameter of the sheil, and the umbilical margin is rounded. The entire shell is smooth, without any trace of ribs or nodes. The suture is well preserved and very simple. It shows a very broad ventral lobe, a broad first lateral saddle with two incipient marginal lobes, a broad first lateral lobe with a suggestion of an incipient marginal lobe on the outer side, a simple second lateral saddle and lobe, and one auxiliary saddle and lobe.

The generic assignment of this little ammonite is uncertain. On the basis of Hyatt's figures of the sutures of young Metengonoceras and Coelopoceras ${ }^{9}$ it could scarcely belong to those genera of sharp-ventered ammonites, both of which are known to occur in the Colorado group of the Interior province of North America. Of other genera its suture appears to be proportioned more like that of Pseudotissotia than of any otker genus, and it is therefore tentatively assigned to Pseudotissotia and to the subgenus Choffaticeras because it shows no trace of ventrolateral keels or nodes.

9 Hyatt, Alpheus, Pseudoceratites of the Cretaceous: U. S. Geol. Survey Mon. 44, pl. 10, figs. 10-12; pl. 27, fig. 13, 1903.

\section{Helicoceras pariense White?}

Plate XX, figures 5-6.

A single fragment of a small cephalopod that appears to have had an open coil in a single plane was uncovered in preparing the type of Vascoceras thomi. It suggests very strongly young Helicoceras pariense White, ${ }^{10}$ though the specimen is insufficient to warrant an unquestioned assignment to that species. The suture is not visible, but the form and sculpture agree closely with those of the specimen figured by Stanton.

Hyatt ${ }^{11}$ referred Helicoceras pariense White to his genus Exiteloceras, but the writer prefers to use the more general name here.

\section{Inoceramus labiatus (Schlotheim).}

Plate XIV, figures 3-5.

A number of specimens of this widespread species accompany the other fossils of the collection. They are mostly of small size but do not depart in any way from typical shells from other localities.

Inoceramus sp.

Plate XIV, figure 6.

A single small specimen of a relatively coarse-ribbed, transversely elongated species of Inoceramus is contained in the collection. It resembles in some respects several different species but is hardly sufficient for certain identification.

10 Stanton, T. W., The Colorado formation and its invertebrate fauna: U. S. Geol. Survey Bull. 106, p. 164, pl. 35, figs. 2-4, 1893.

11 Hyatt, Alpheus, The phylogeny of an acquired characteristic: Am. Philos. Soc. Proc., vol. 32, p. 577, 1894. 
PLATES XI-XXI. 

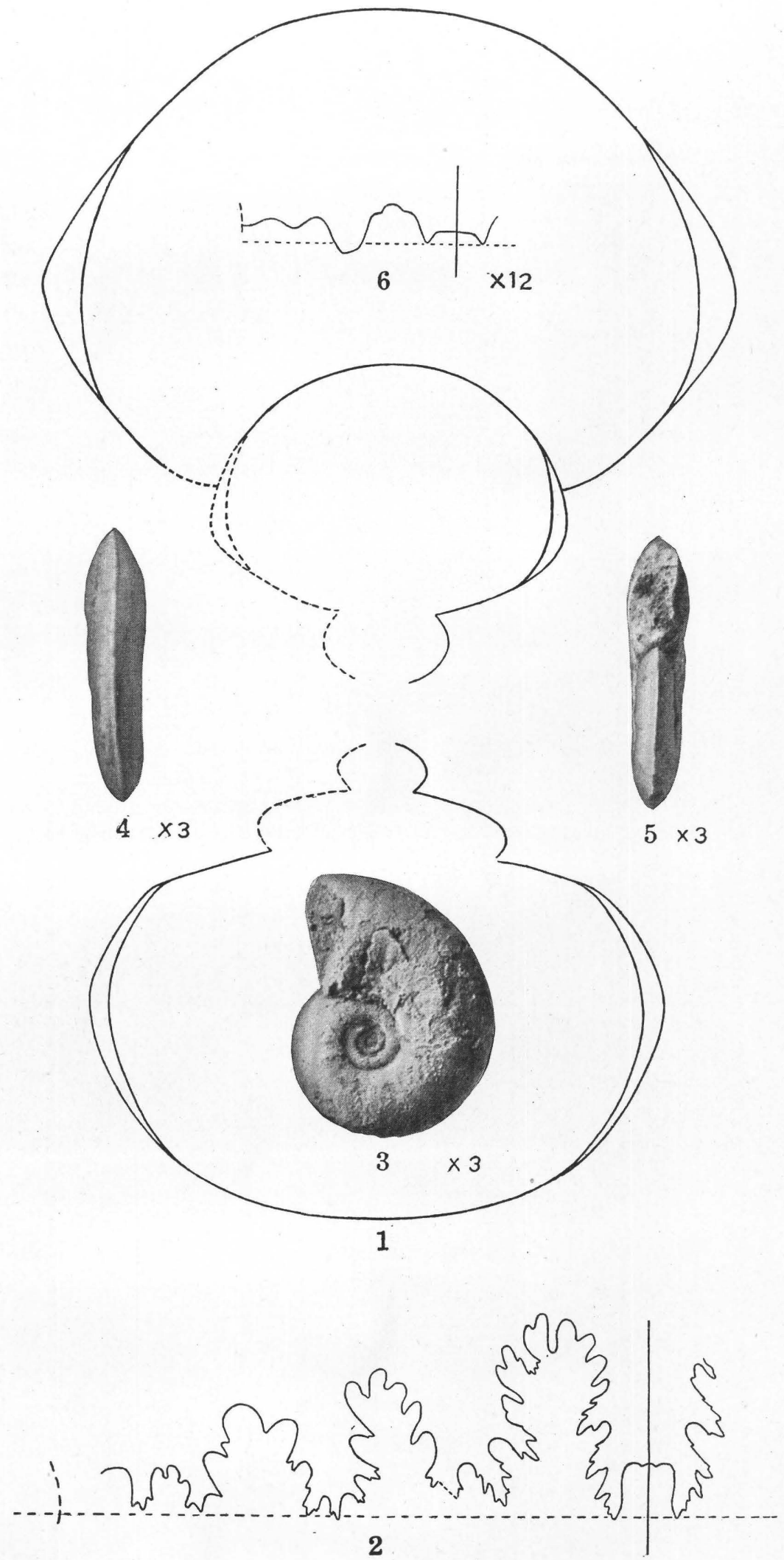

FOSSILS FROM THE COLORADO GROUP OF SOUTHERN MONTANA.

1-2. Vascoceras thomi Reeside, n. sp. Type specimen (U. S. Nat. Mus. catalog No. 32535). 1, Cross section at diameter of 165 millimeters; $\boldsymbol{2}$, suture at diameter of 100 millimeters.

3-6. Pseudotissotia (Choffaticeras) sp.? 3, Side view; 4, rear view; 5, front view; 6, suture. (U. S. Nat. Mus. catalog No.32541.) 

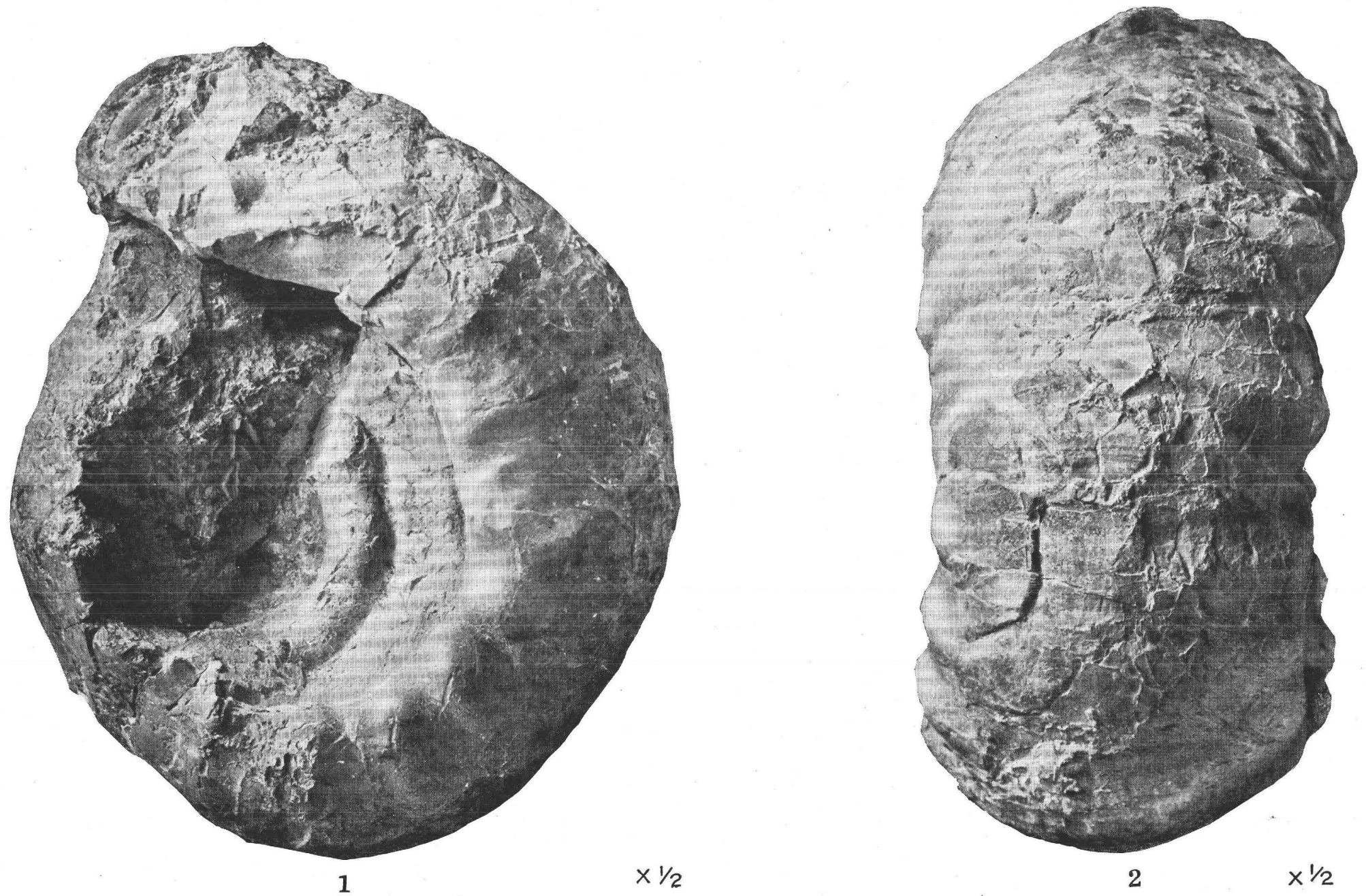

FOSSILS FROM THE COLORADO GROUP OF SOUTHERN MONTANA. Vascoceras thomi Reeside, n. sp. 1, Side view; 2, rear view. (U. S. Nat. Mus. catalog No. 32536.) 


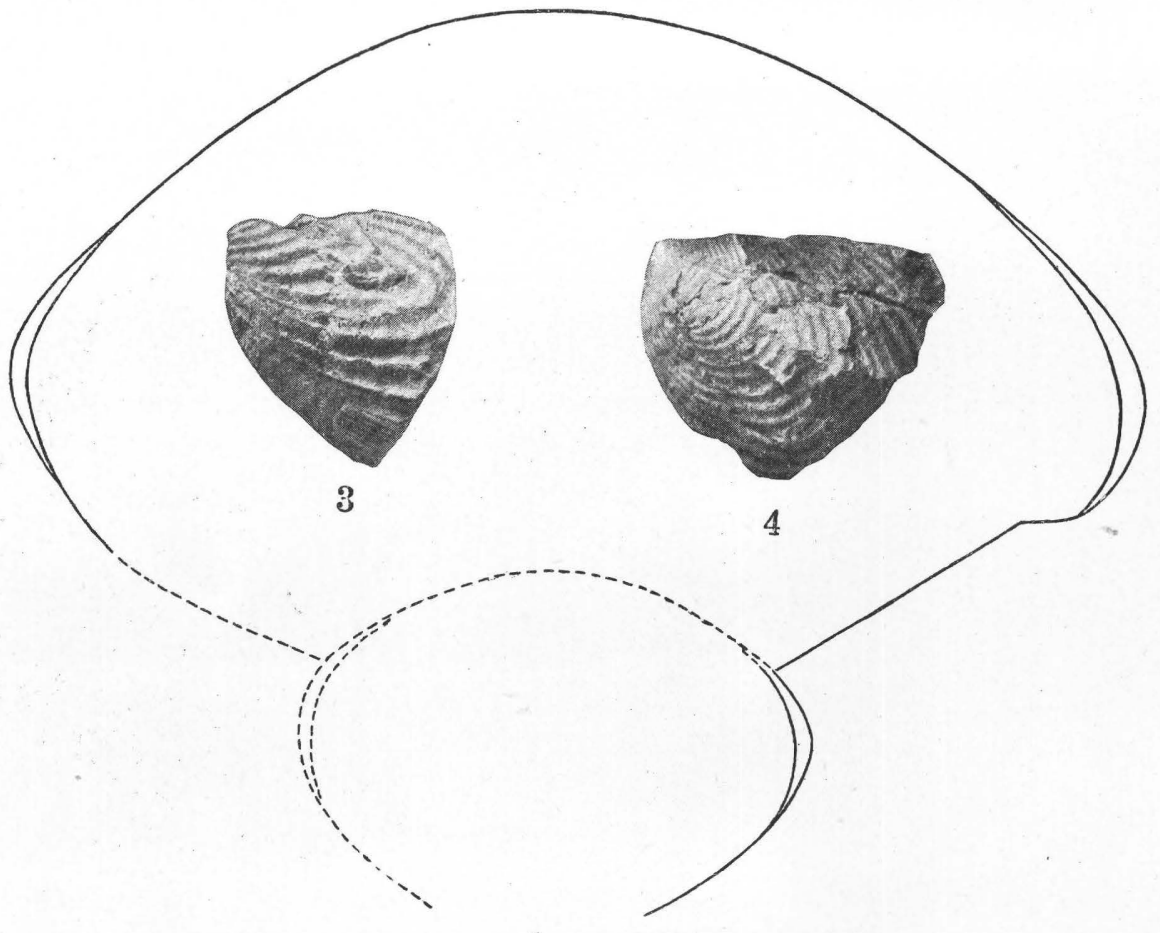

1
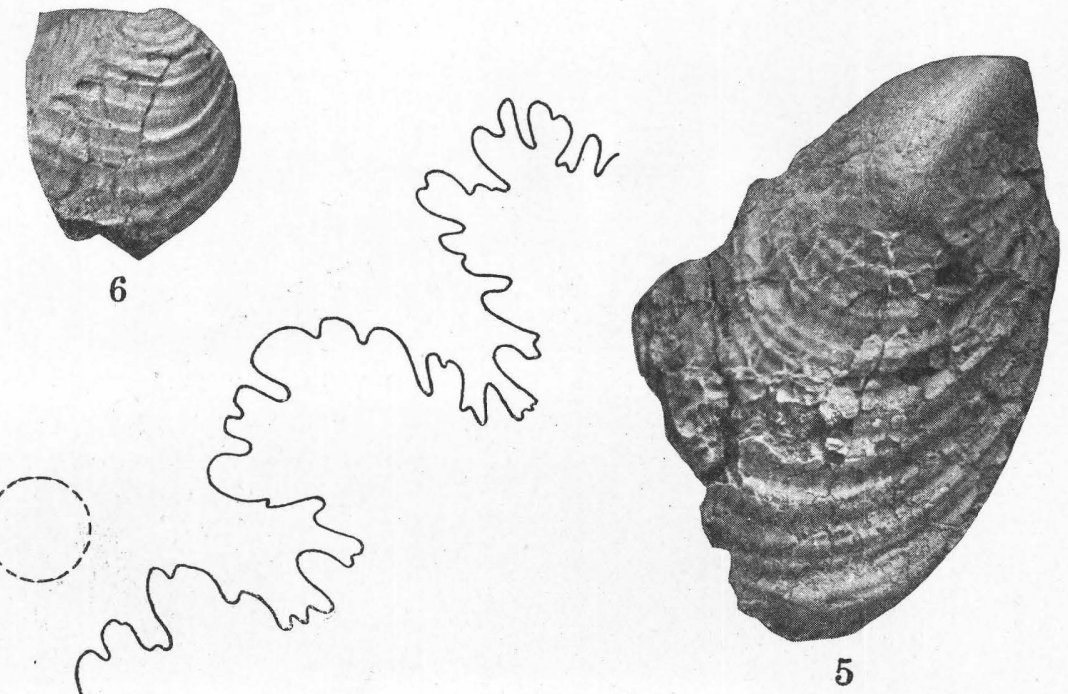

5<smiles>C1CCCCCC1</smiles>

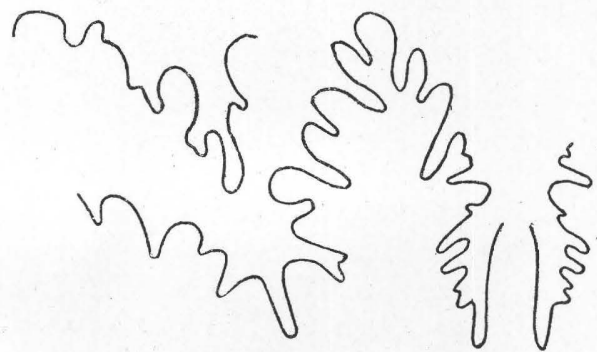<smiles>C1CCCCCC1</smiles>

FOSSILS FROM THE COLORADO GROUP OF SOUTHERN MONTANA.

1-2. Vascoceras thomi Reeside, n. sp. 1, Cross section of whorl at diameter of 200 millimeters; 2 , parts of three sutures at diameter of 150 millimeters of specimen shown on Plate XIII. (U. S. Nat. Mus. catalog No. 32536 .)

3-5. Inoceramus labiatus (Schlotheim). (U. S. Nat. Mus. catalog Nos. 32540 and 32543 .)

6. Inoceramus sp. (U.S. Nat. Mus. catalog No. 32542.) 
U. S. GEOLOGICAL SURVEY

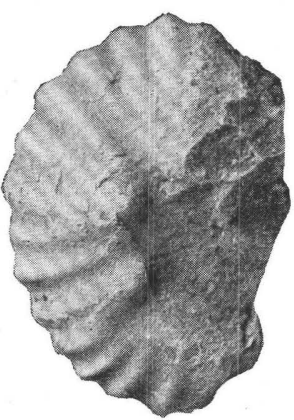

3

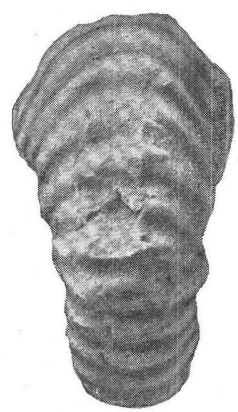

4
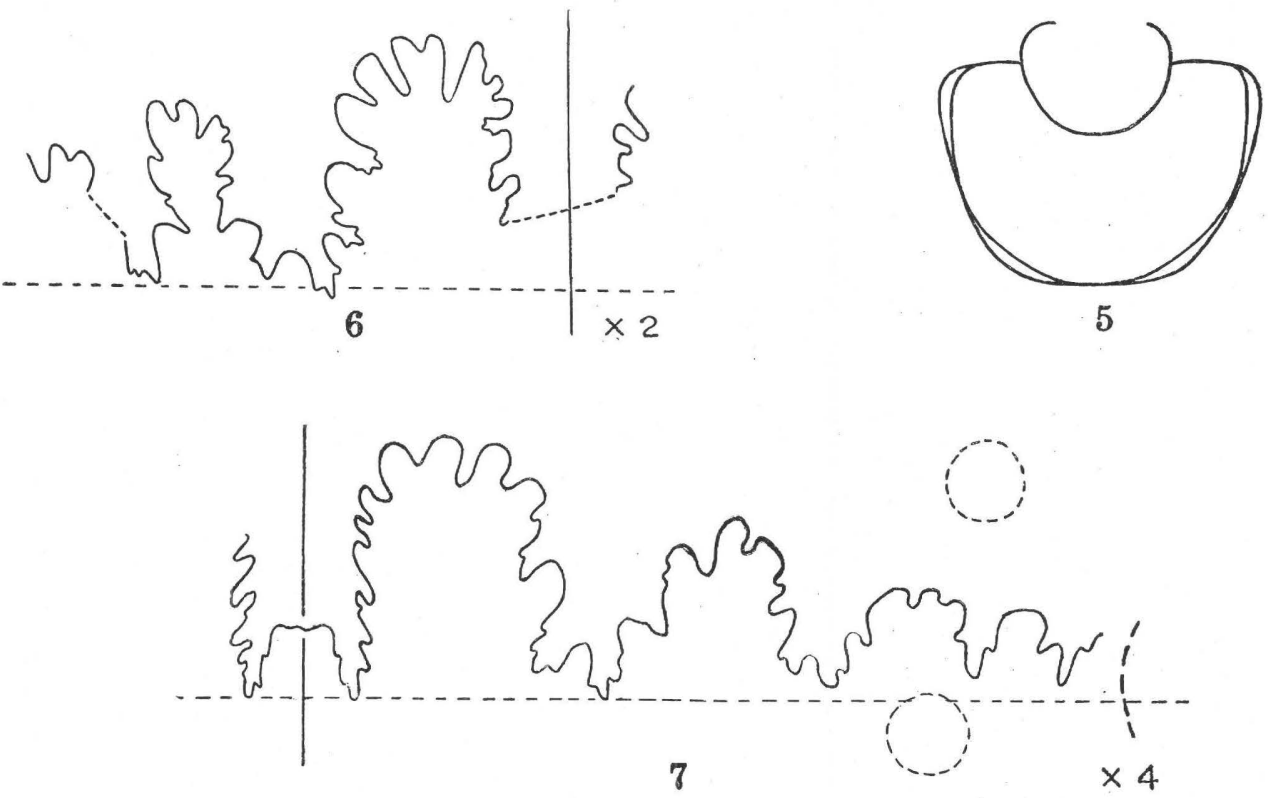

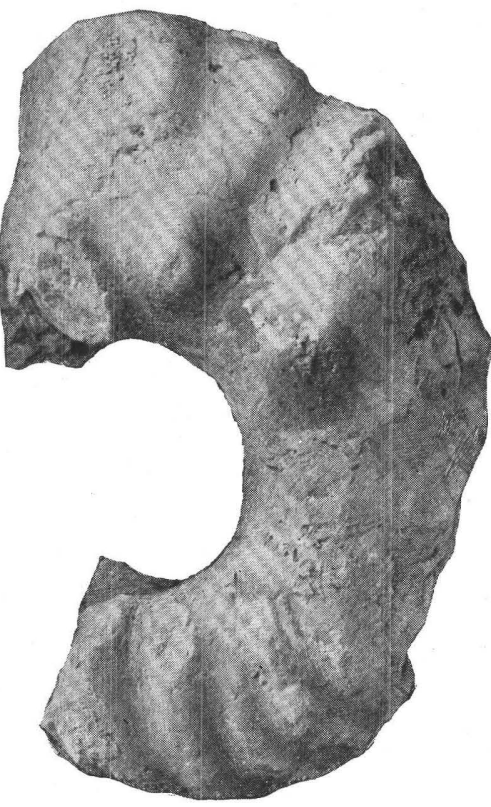

1

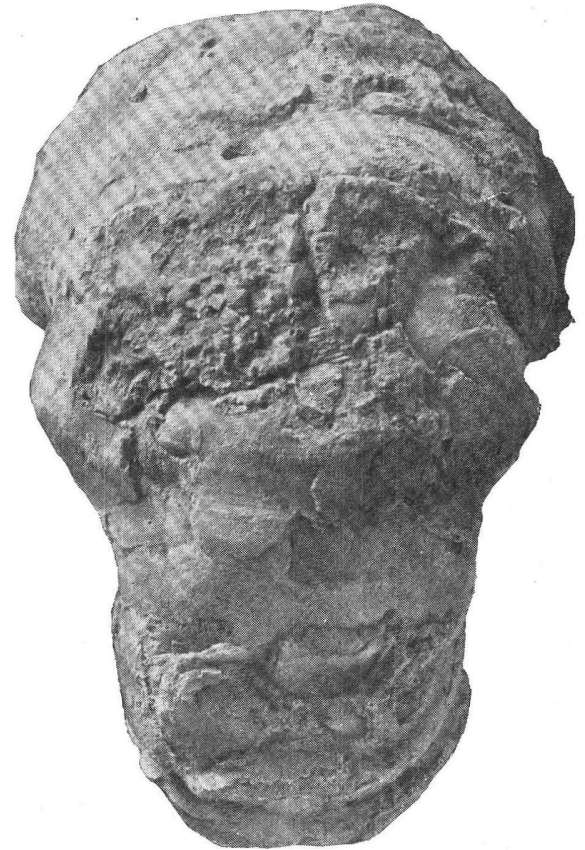

2

FOSSILS FROM THE COLORADO GROUP OF SOUTHERN MONTANA.

Vascoceras thomi Reeside, n. sp. 1, Side view of outer whorl; 2, rear view of outer whorl; 3, side view of inner whorl; 4, rear view of inner whorl; $\mathbf{5}$, cross section at diameter of 75 millimeters; 6, suture at diameter of 55 millimeters; $\boldsymbol{7}$, suture at diameter of 30 millimeters. (U. S. Nat. Mus. catalog No. 32536.) 


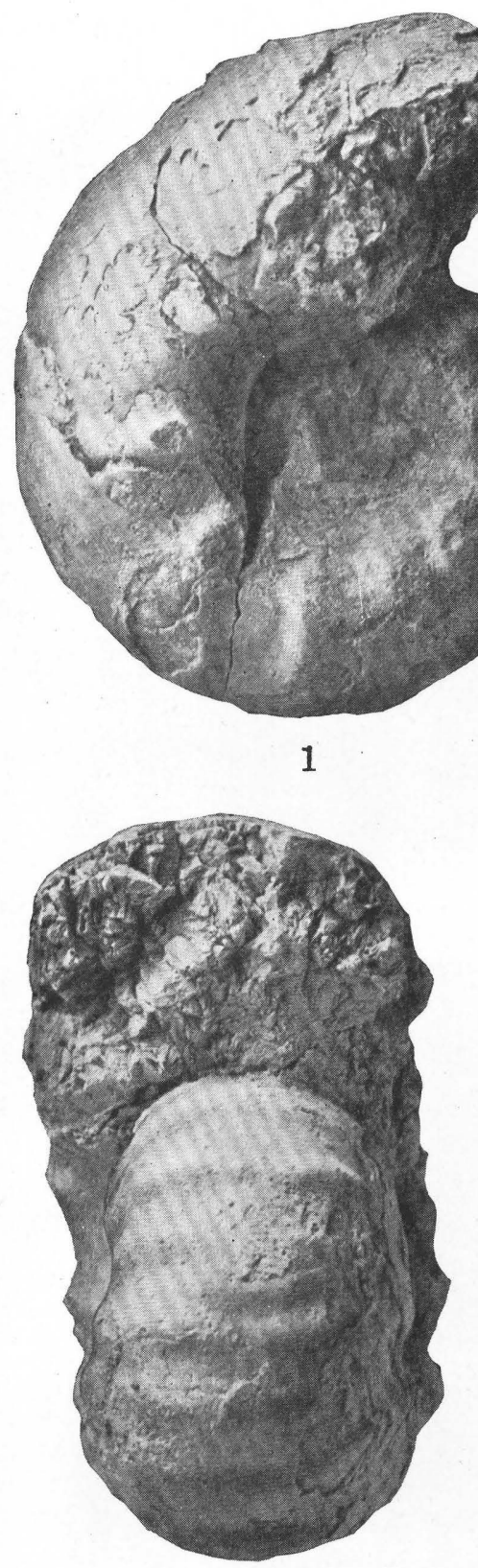

3

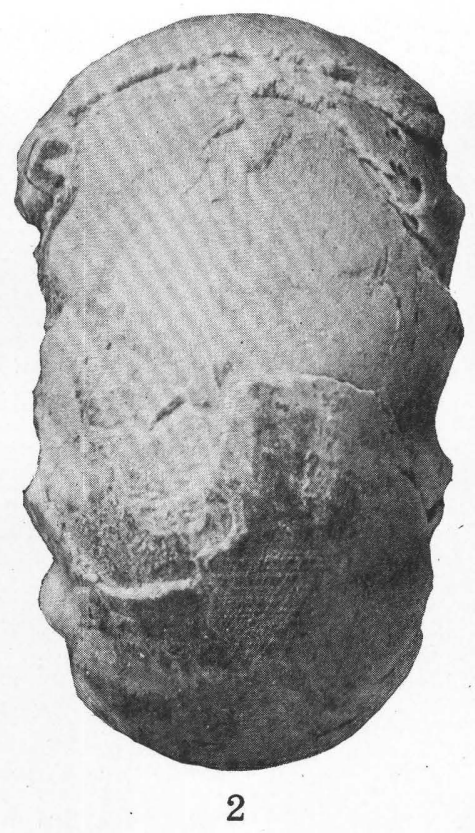

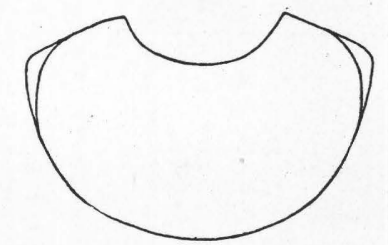

5
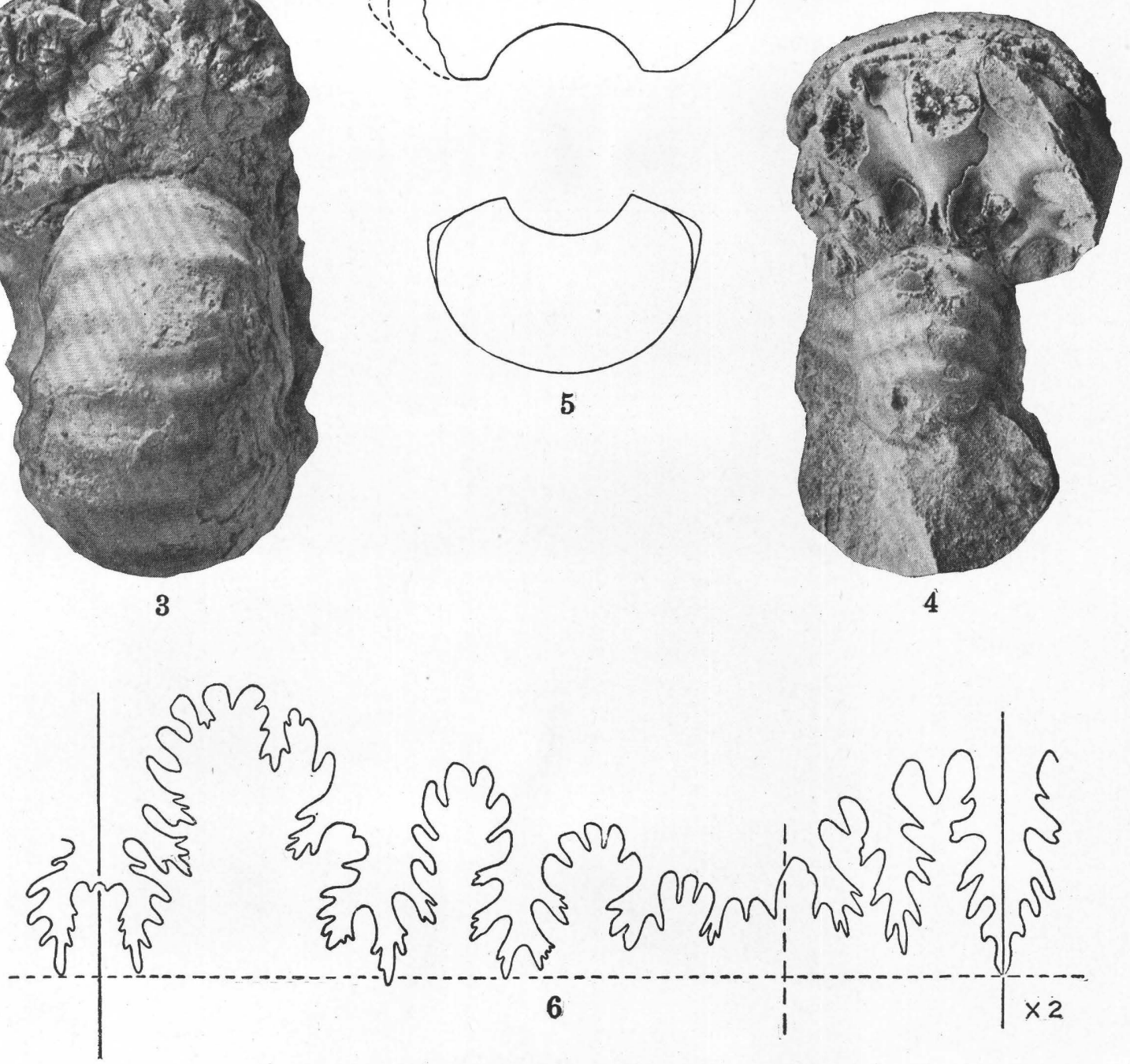

FOSSILS FROM THE COLORADO GROUP OF SOUTHERN MONTANA.

Vascoceras thomi Reeside, n. sp. 1-3, Entire specimen; 1, side view; 2, rear view; 3, front view; 4, rear view with part of outer whorl removed; 5, cross section at diameter of 70 millimeters; 6, suture at diameter of 60 millimeters. (U. S. Nat. Mus. catalog No. 32536.) 

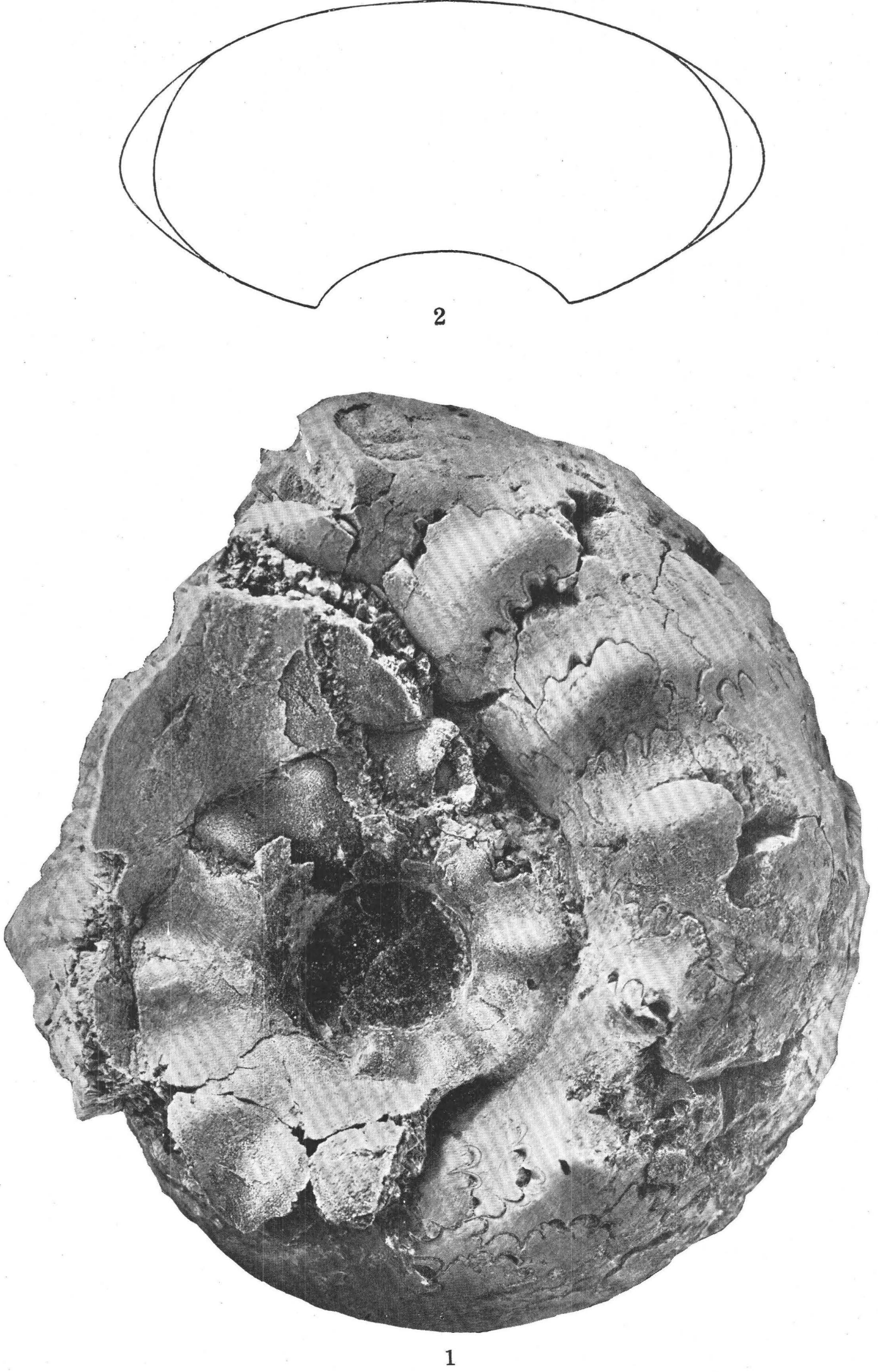

FOSSILS FROM THE COLORADO GROUP OF SOUTHERN MONTANA。

Vascoceras moultoni Reeside, ṅ. sp. Type specimen (U. S. Nat. Mus. catalog No. 32537). 1, Side view; 2, rear view. 

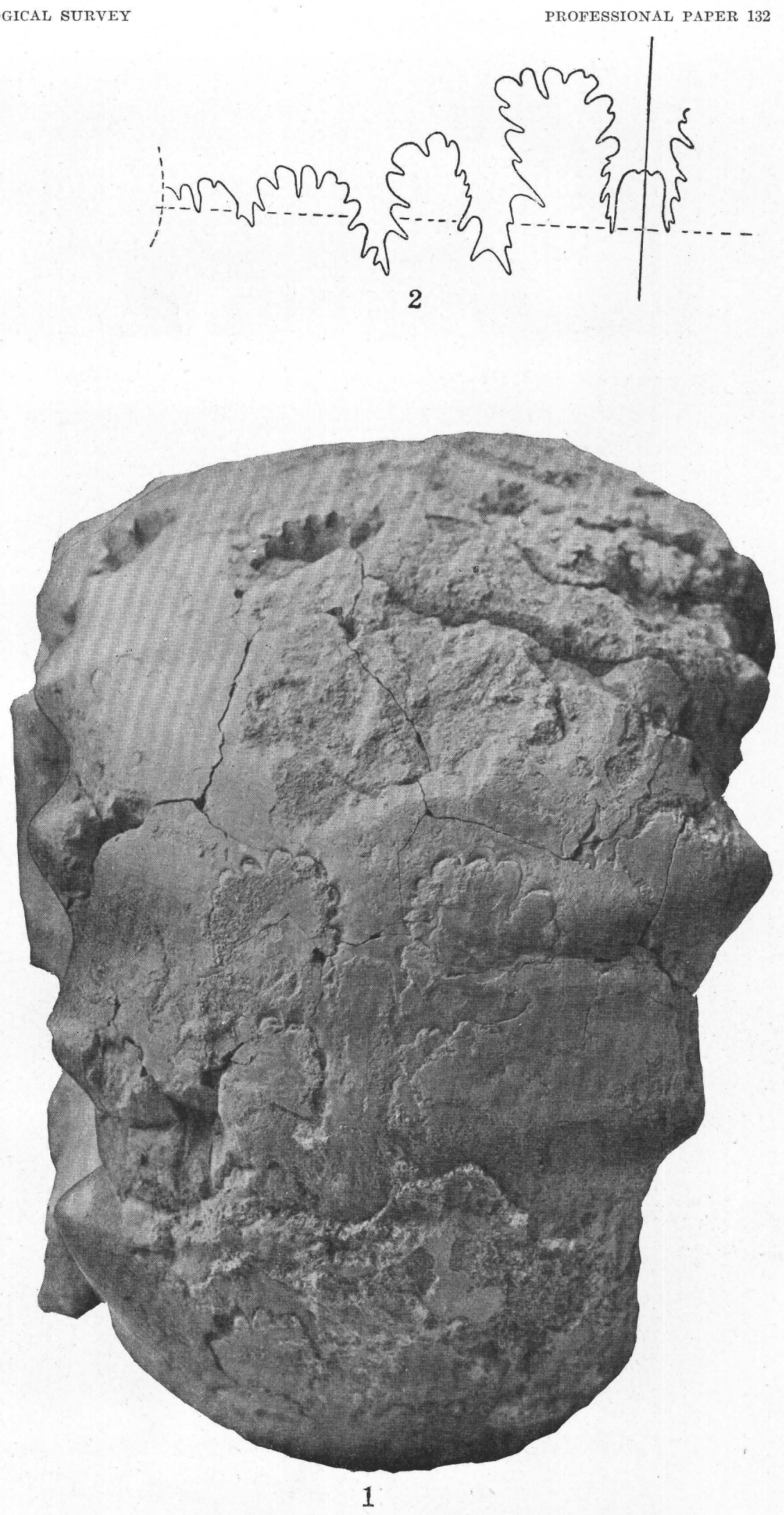

FOSSILS FROM THE COLORADO GROUP OF SOUTHERN MONTANA.

Vascoceras moultoni Reeside, n. sp. Type specimen (U. S. Nat. Mus. catalog No. 32537). 1, Cross section of whorl at diameter of 150 millimeters; 2 , suture at diameter of 110 millimeters. 


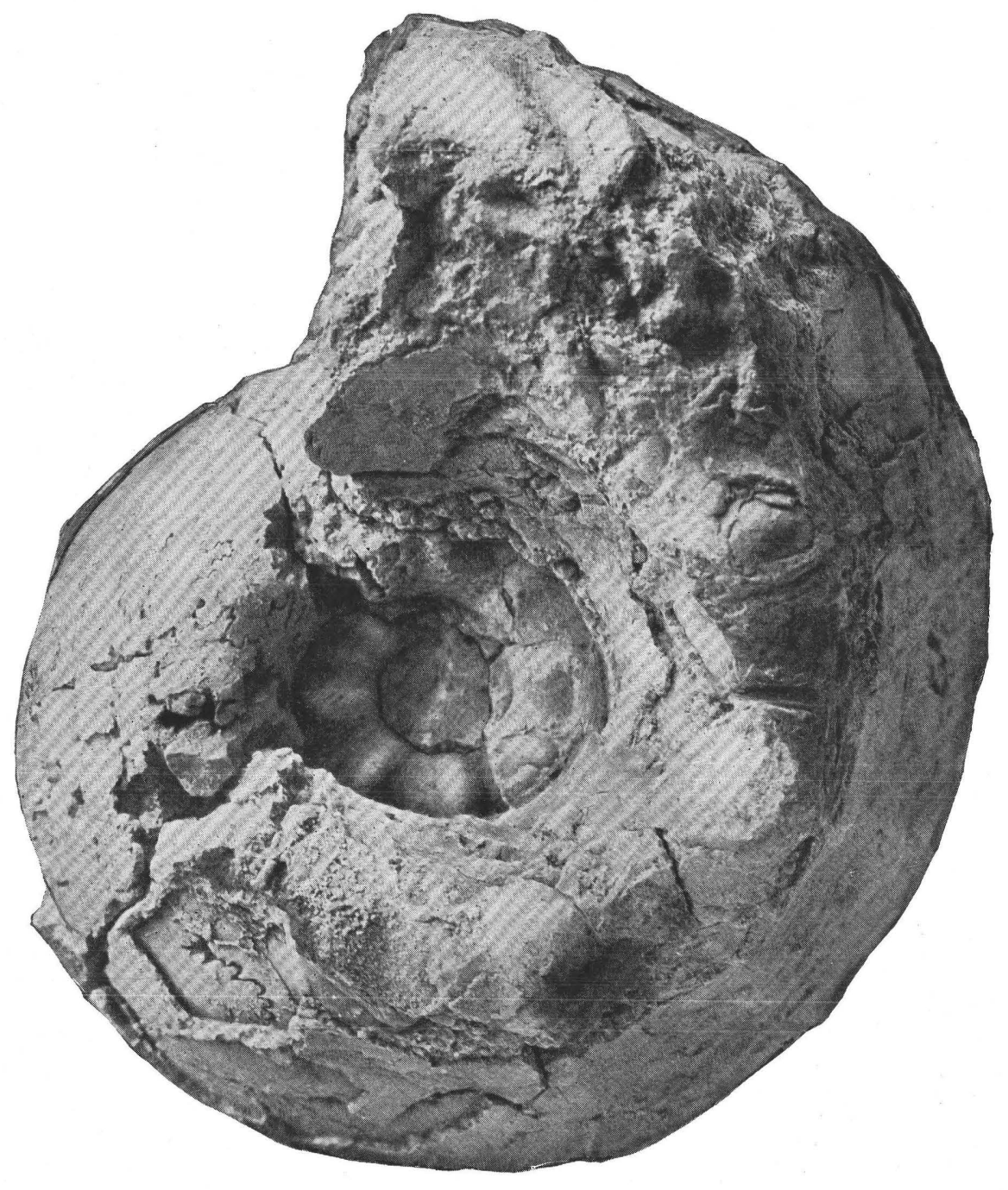

1

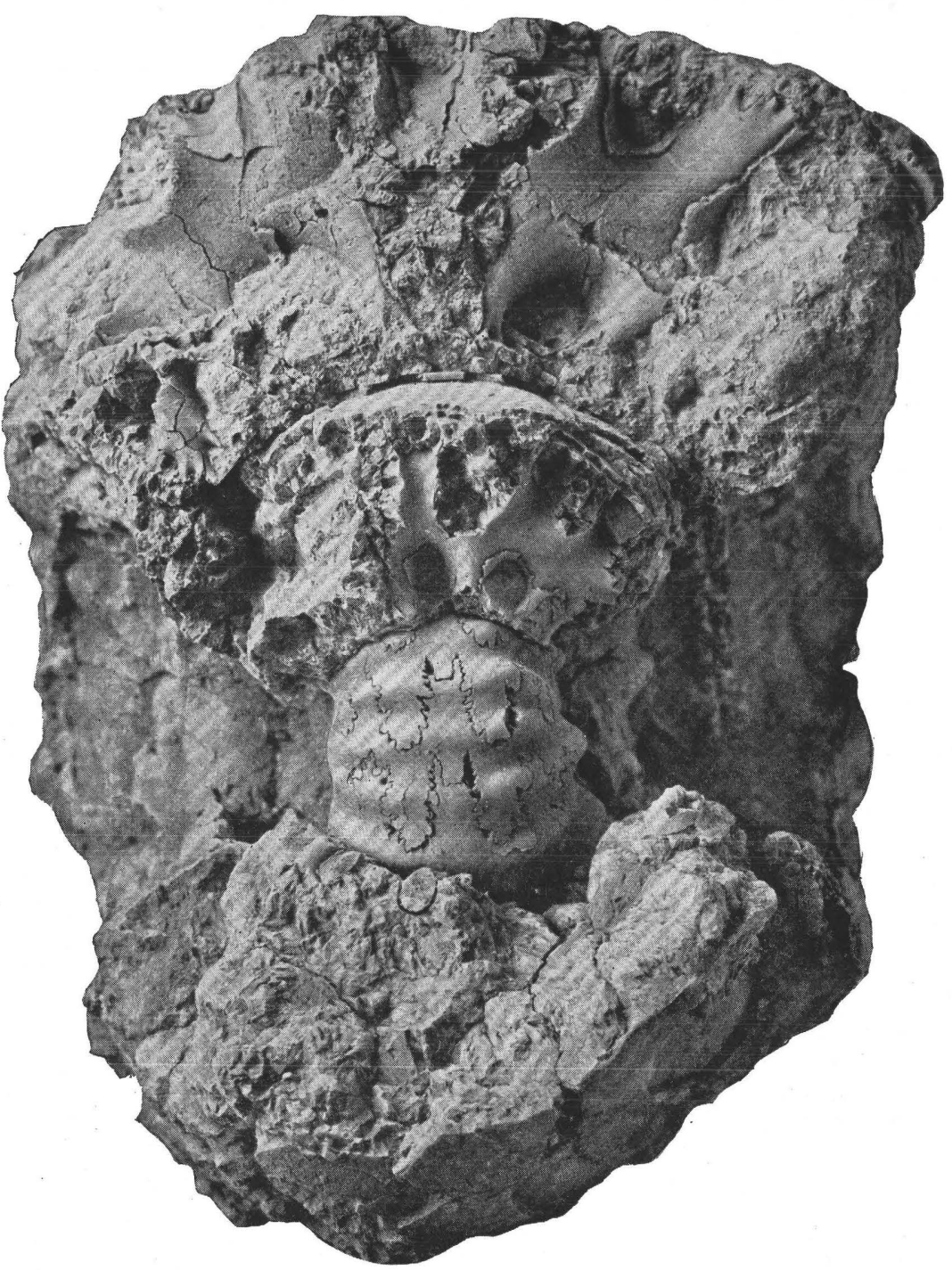

2

FOSSILS FROM THE COLORADO GROUP OF SOUTHERN MONTANA.

Vascoceras stantoni Reeside, n. sp. Type specimen (U. S. Nat. Mus. catalog No. 32532). 1, Side view of whole specimen; 2, front view with part of outer whorl removed . 

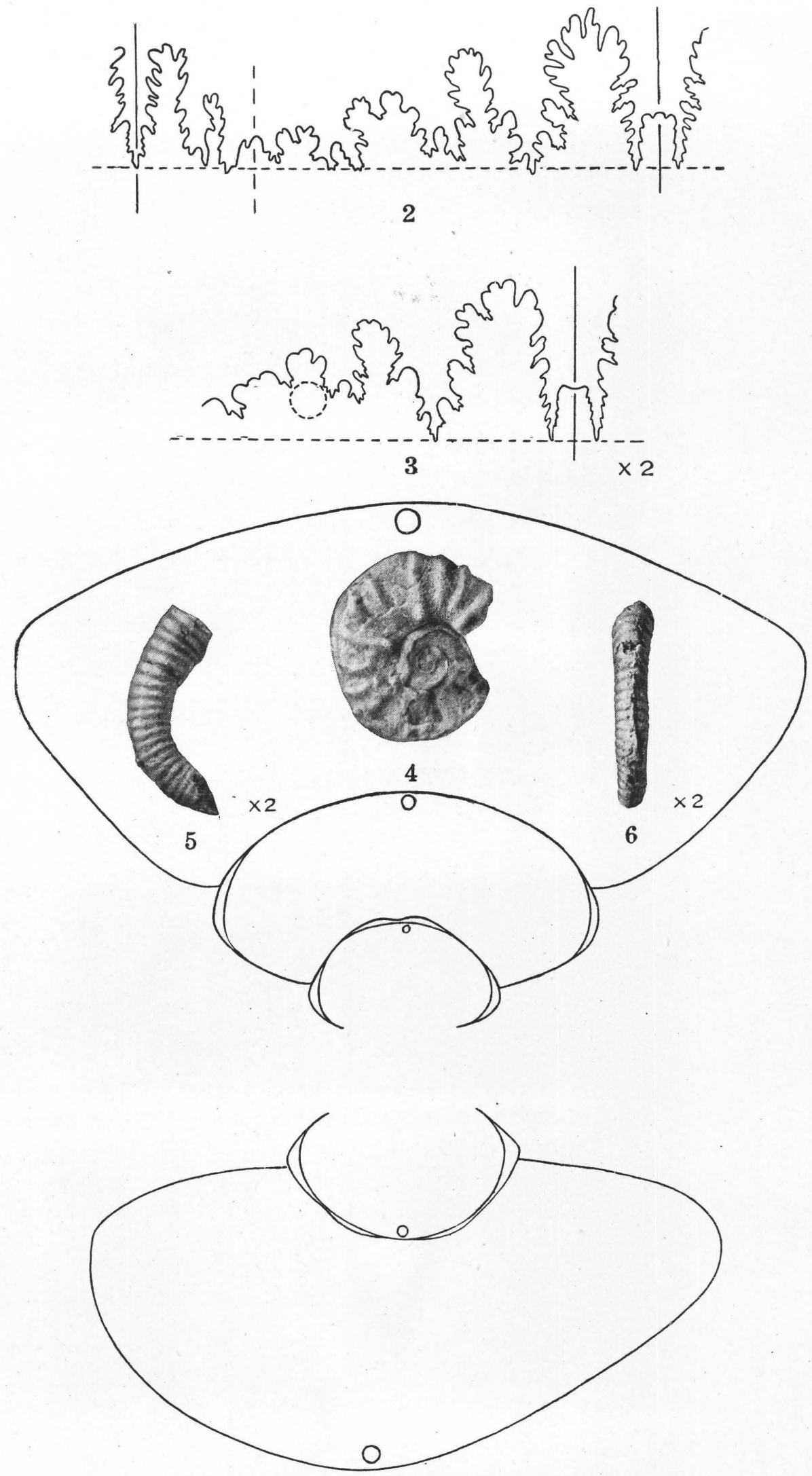

1

FOSSILS FROM THE COLORADO GROUP OF SOUTHERN MONTANA.

1-3. Vascoceras stantoni Reeside, n. sp. Type specimen (U. S. Nat. Mus. catalog No. 32532). 1, Cross section at diameter of 150 millimeters; $\mathbf{2}$, suture at diameter of 90 millimeters; $\mathbf{3}$, suture at diameter of 40 millimeters.

4. Vascoceras sp. Side view of squeeze showing young whorls. (U. S. Nat. Mus. catalog No. 32538,)

5-6. Helicoceras pariense White? 5, Side view; 6, rear view. (U. S. Nat. Mus. catalog No. 32539.) 


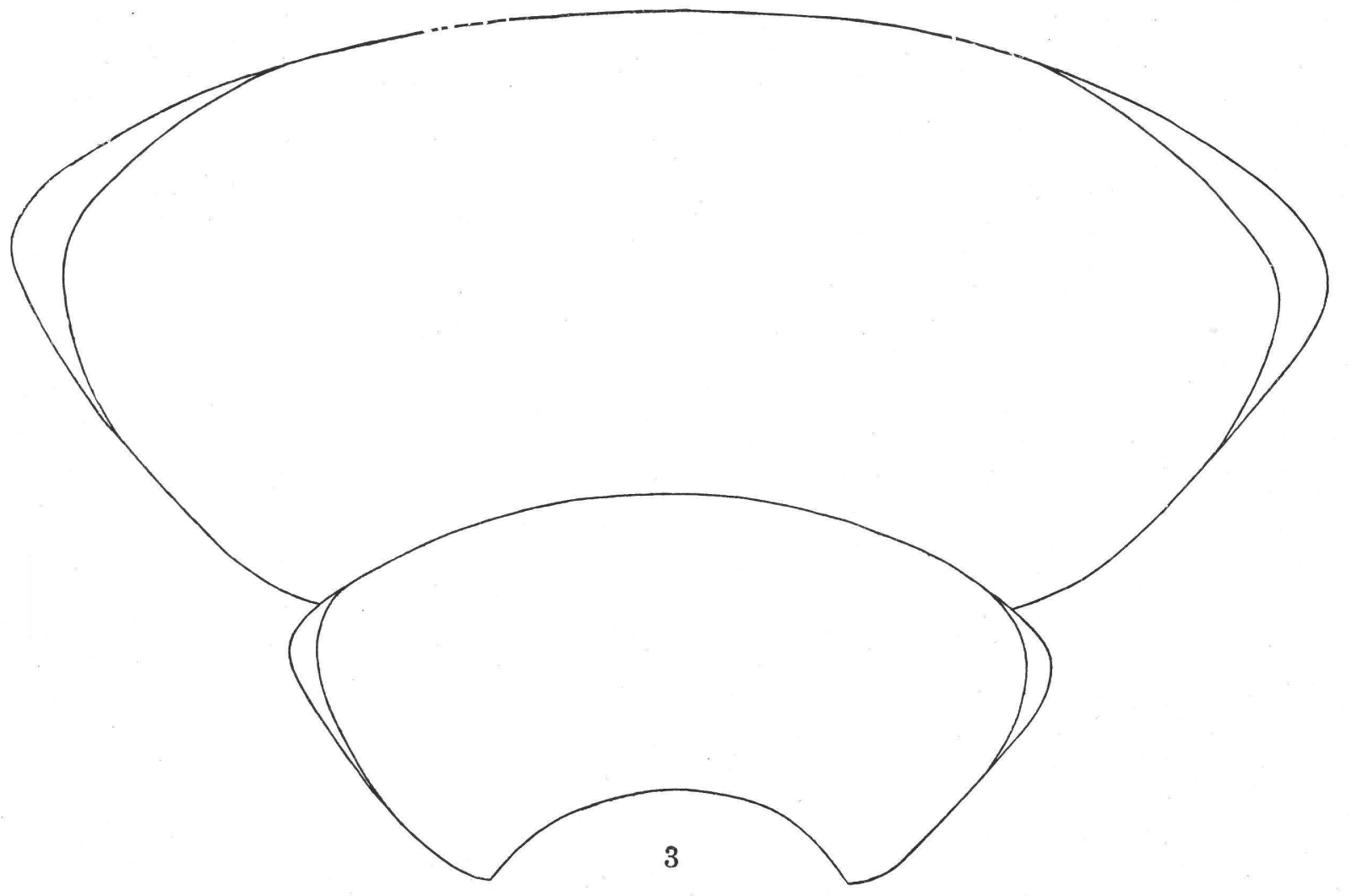

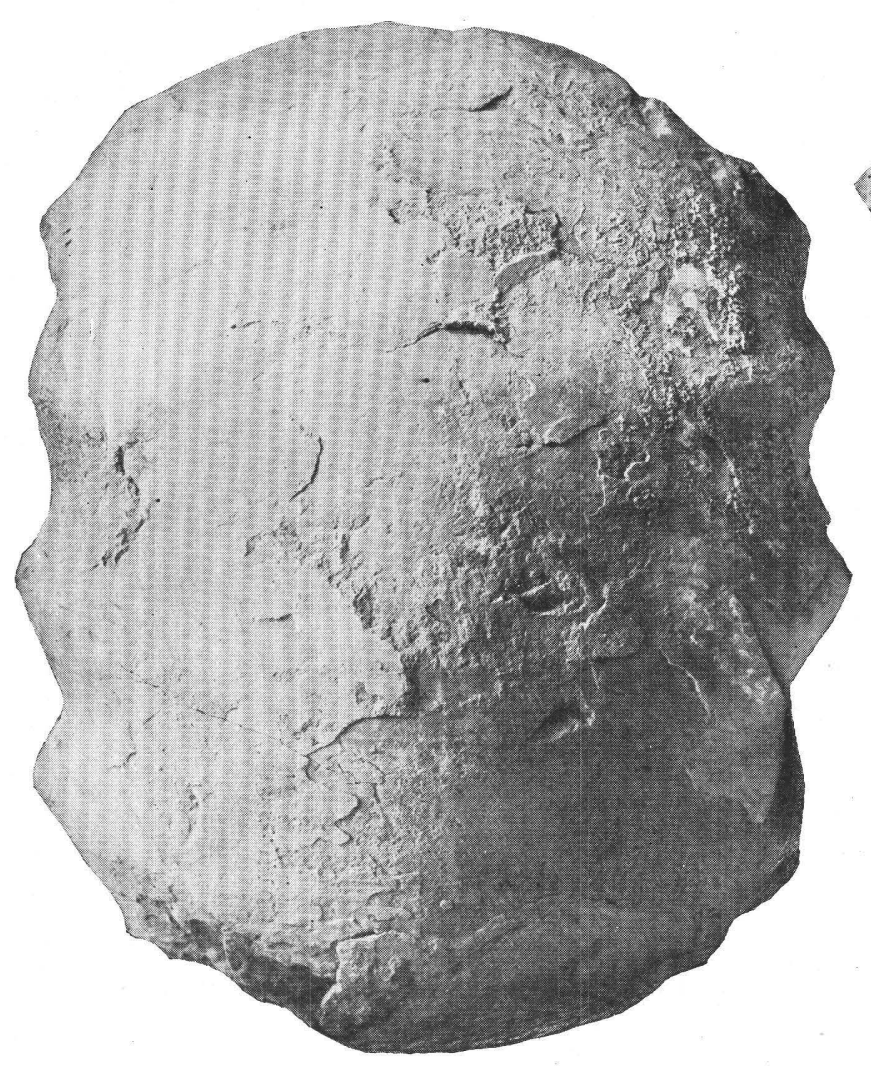

2 $x \frac{1}{2}$

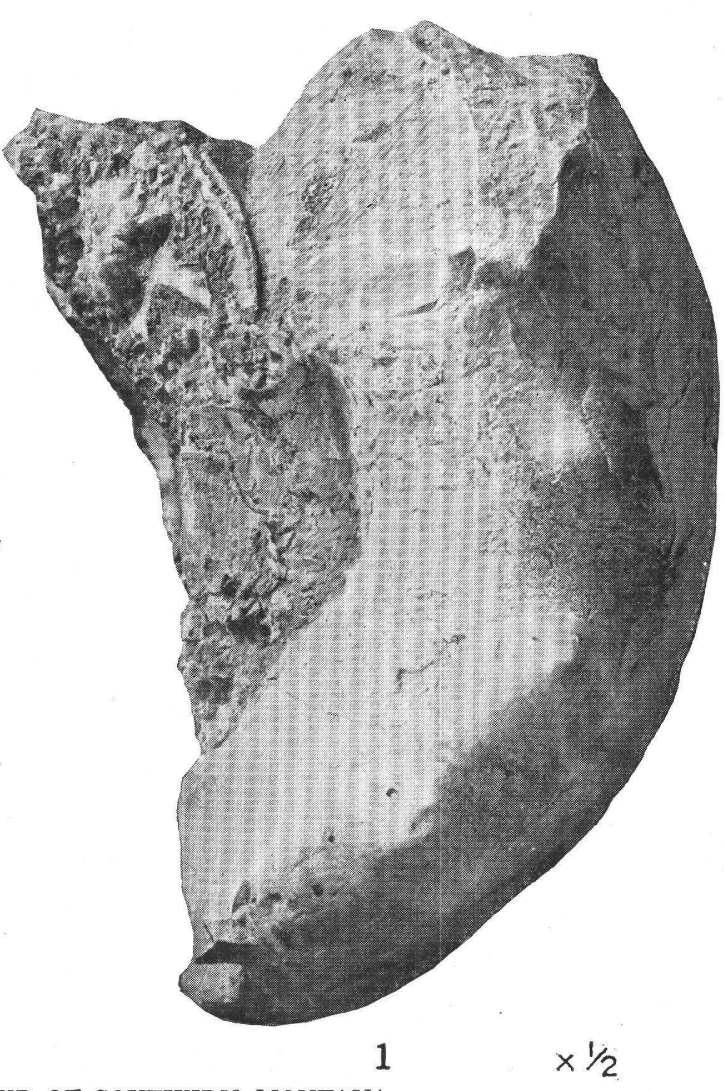

FOSSILS FROM THE COLORADO GROUP OF SOUTHERN MONTANA.

Vascoceras stantoni Reeside, n. sp. 1, Side view; 2, rear view; 3, cross section, slightly reduced, at diameter of 240 millimeters. (U. S. Nat. Mus. catalog No. 32533.) 